\title{
Synergistic Effect of Calcium Carbonate and Biobased Particles for Rubber Reinforcement and Comparison to Silica Reinforced Rubber
}

\section{Lei Jong}

National Center for Agricultural Utilization Research, Plant Polymer Research, Peoria, IL 61604, USA; lei.jong@usda.gov

Received: 26 July 2020; Accepted: 11 August 2020; Published: 13 August 2020

\begin{abstract}
Silica is a standard commercial filler to reduce rolling resistance of tires. The co-filler of nano-size calcium carbonate and bio-based particles also produce reinforced rubber with similar tensile properties and rolling resistance as silica reinforced rubber. A synergistic effect between calcium carbonate and soy protein nanoparticles was observed to produce reinforced rubber with good tensile properties and low rolling resistance. The protein increases the effective crosslink density and moduli of calcium carbonate reinforced rubber. Stearic acid coated calcium carbonate particles have a greater reinforcement effect than the uncoated calcium carbonate particles. Mechanical properties of the composites can be adjusted through the complimentary effect of these two fillers. The composite that contains $60 \%$ protein and $40 \%$ coated calcium carbonate has mechanical properties comparable to that of the silica reinforced rubber. The temperature and strain dependent dynamic mechanical properties, as well as the stress relaxation behaviors of these rubbers, reveal synergistic effect between the co-fillers. This development demonstrates an economical method to produce useful reinforced rubbers.
\end{abstract}

Keywords: rubber; filler; silica; mechanical properties

\section{Introduction}

Different types of fillers are used to improve the material performance and reduce the cost of reinforced rubbers. For the optimization of performance and cost, combinations of fillers are also used. Through synergistic effect between fillers, performance can be augmented and cost decreased. For rubber applications, carbon black and silica are the two major fillers for these applications. The other filler that has been widely used in rubbers for cost reduction while not compromising the mechanical properties is calcium carbonate. However, nano-sized calcium carbonate nanoparticles can also be used to improve mechanical properties of rubbers. Calcium carbonate has been used to improve modulus and impact strength of acrylonitrile-butadiene-styrene [1], compressive strength, elastic modulus, and elongation of epoxy resin [2], fractural toughness in polypropylene [3-7], tensile strength of high density polyethylene [8-10], and mechanical properties of polyvinylchloride [11-13], poly(propylene carbonate) [14], and low density polyethylene [15]. The effects of calcium carbonate were also investigated in natural rubber [16-23], styrene-butadiene rubber [24,25], ethylene-propylene-diene rubber [26], acrylonitrile butadiene rubber [27,28], and butadiene rubber [29]. Despite nano-sized calcium carbonate particles having been used in different rubbers, the general characteristic of rubber composites reinforced by calcium carbonate particles is that they yield lower modulus compared to rubbers reinforced with carbon black or silica. To produce high performance, low cost, and environmentally friendly rubber composites, soy protein nanoparticles have great potential to significantly improve the mechanical properties of calcium carbonate reinforced rubbers, and this 
has not been reported. In the current development, soy protein nanoparticles were incorporated into natural rubber latex and dried to form protein reinforced natural rubber. The traditional rubber compounding process was then used to incorporate calcium carbonate into the protein reinforced natural rubber in dry state. This approach represents an economical method to significantly improve calcium carbonate reinforced rubbers. These new rubber composites were characterized to understand their structure and properties. The rubber composites reinforced with both calcium carbonate and soy protein nanoparticles show significantly improved mechanical properties, and have the potential to be used in various molded rubber applications. The silica reinforced rubber composite processed under the same conditions is also compared, to give an indication of potential applications.

\section{Experimental}

\subsection{Materials}

Calcium carbonate and stearic acid modified calcium carbonate were obtained from US Research Nanomaterials, Inc. (Houston, TX, USA). The particle size of the white calcium carbonate is $50 \mathrm{~nm}$ with cubic particle shape. Stearic acid coated calcium carbonate contains 1-2 wt.\% stearic acid. Calcium hydroxide was from Fisher Scientific (Waltham, MA, USA). Spray dried soy protein (SP) (trade name Ardex F) was from Archer Daniels Midland Company (Decatur, IL, USA). Low ammonia (LA) NR (natural rubber) latex was from Centrotrade Rubber USA, Inc. (Chesapeake, VA, USA). Silica coated with silane coupling agent (Agilon 400G-D) was obtained from PPG (New Milford, CT, USA). Rubber curing accelerator, $N$-cyclohexyl-2-benzothiazolesulfenamide, was from Akrochem Co. (Akron, OH, USA). Sulfur, 1.3-diphenylguanidine (DPG), zinc oxide, 2,2'-Methylenebis(6-tert-butyl-4-methylphenol), and stearic acid were from Alfa Aesar (Ward Hill, MA, USA).

\subsection{Preparation of Composites}

Aqueous protein dispersion with $8.5 \%$ soy protein was prepared at $40{ }^{\circ} \mathrm{C}$. Calcium hydroxide at $2.2 \%$ based on the weight of soy protein was then added to the dispersion and the protein was hydrolyzed at $95^{\circ} \mathrm{C}$ for $2 \mathrm{~h}$ under stirring. The hydrolyzed dispersion after cooling was microfluidized once through a $200 \mu \mathrm{m}$ diamond and an $80 \mu \mathrm{m}$ ceramic interaction chambers connected in series. The microfluidizer (M-100P, Microfluidics, Newton, MA, USA) was operated at a pressure of $159 \mathrm{MPa}$ and the temperature was controlled at about $30{ }^{\circ} \mathrm{C}$ by cold water. The final concentration of the SP dispersion is $8.4 \%$. Soy protein particles are non-spherical aggregates of hydrolyzed protein fragments [30,31].

The SP dispersion was then mixed with NR latex at different ratios. The whole mixture with a solid content of $\sim 14 \%$ was mixed at $\mathrm{pH} 10$ for $30 \mathrm{~min}$ at room temperature. For convenience in our laboratory, the dispersion was freeze-dried. Other drying methods may also be used. After drying the aqueous dispersion, the dry mixture of NR and SP was compounded with different amount of calcium carbonate and rubber chemicals (stearic acid, zinc oxide, and antioxidant) in a Brabender mixer (ATR Plasti-corder, C.W. Brabender Instruments, Inc., South Hackensack, NJ, USA). The compositions of these rubber samples are summarized in Table 1 . The material volume is $72 \%$ of the mixing bow 1 volume. All components were added at once except sulfur and accelerator, and then mixed for 20 min at $60 \mathrm{rpm}$ with an initial temperature of $80^{\circ} \mathrm{C}$. After the mixing, sulfur and accelerator were added and mixed for $3 \mathrm{~min}$ at an initial temperature of $80^{\circ} \mathrm{C}$. The mixture removed from the Brabender mixer was compression molded at $5 \mathrm{MPa}$ and $150{ }^{\circ} \mathrm{C}$ for $15 \mathrm{~min}$, which exceeds the time for $100 \%$ cure for all the samples. In this inclusive equal comparison, the curing conditions are the same for all samples, different from comparing only their optimum properties. In the equal comparison, both positive and negative effects are included. At 15 min curing time, all samples have an extent of cure at 90-100\%, because of reversion to different extent in samples. 
Table 1. Rubber composition.

\begin{tabular}{cccccccccccc}
\hline & Ca & CP2 & CP4 & CP6 & CP8 & P & CS & CSP2 & CSP4 & CSP6 & CSP8 \\
\hline NR & 100 & 100 & 100 & 100 & 100 & 100 & 100 & 100 & 100 & 100 & 100 \\
Ca & 50 & 40 & 30 & 20 & 10 & 0 & 0 & 0 & 0 & 0 & 0 \\
CS & 0 & 0 & 0 & 0 & 0 & 0 & 50 & 40 & 30 & 20 & 10 \\
P & 0 & 10 & 20 & 30 & 40 & 50 & 0 & 10 & 20 & 30 & 40 \\
\hline
\end{tabular}

$\mathrm{Ca}=$ calcium carbonate, $\mathrm{CS}=$ stearic acid coated calcium carbonate, $\mathrm{P}=$ protein. Other components in the formulation are $1 \mathrm{phr}$ antioxidant, $2 \mathrm{phr}$ stearic acid, $5 \mathrm{phr}$ zinc oxide, $2 \mathrm{phr}$ sulfur, and $2 \mathrm{phr}$ CBS. phr $=$ parts per hundred parts of rubber.

For comparison, silica reinforced rubbers coated with and without silane coupling agent were prepared at $50 \mathrm{phr}$ under the same processing conditions as all other samples. An additional silane coated silica reinforced rubber composite with 1 phr DPG was also prepared under the same conditions.

\subsection{Physical Characterizations}

The average size of SP particles in water was measured with a Horiba LA-930 laser scattering particle size analyzer (Horiba Instruments, Irvine, CA, USA) that produces volume and number-weighted mean diameters and size distribution. After removing $7 \%$ of particles larger than 0.7 micron by filtration, $93 \%$ of protein particles have a volume-averaged size of $\sim 340 \mathrm{~nm}$ and a number-averaged size of $\sim 230 \mathrm{~nm}$. To measure crosslink density of the composites, weighted samples were immersed in toluene for 7 days at $25^{\circ} \mathrm{C}$. The dry weight of the composites was measured after the swollen samples were dried under vacuum for 3 days at $50^{\circ} \mathrm{C}$. By comparing the swollen and dry composites, volume fraction of NR in a swollen sample was determined. Bound rubber was measured on aged uncured compounds by toluene extraction at $80^{\circ} \mathrm{C}$ for 3 days and vacuum dried. The aged uncured compounds have a certain degree of crosslinks. They are not sticky and can be weighted directly.

\subsection{Mechanical Properties}

To measure the elongation, tensile strength, and modulus, an Instron tensile testing machine (Instron, Norwood, MA, USA) was used. The crosshead speed was $500 \mathrm{~mm} / \mathrm{min}$, with $\sim 2 \mathrm{~mm}$ thick type 2 dumbbell specimens based on ISO 37-2. The type 2 specimen had a test length of $20 \mathrm{~mm}$ and a total length of $75 \mathrm{~mm}$. Five samples were tested for each composite. The elongation was measured with an Instron AutoX750 automatic extensometer. Tear strength was measured using type $\mathrm{T}$ trouser specimen, as described in ASTM D624. The type T specimen has a $40 \mathrm{~mm}$ initial cut at the center of the specimen. The temperature dependent storage and loss modulus was measured with a strain-controlled rheometer (ARES-G2, TA Instruments, Piscataway, NJ, USA) and a torsion rectangular geometry. The samples had an approximate dimension of $50 \times 12.5 \times 5 \mathrm{~mm}$. The temperature dependent modulus was measured at a heating rate of $1{ }^{\circ} \mathrm{C} / \mathrm{min}$ from -70 to $140{ }^{\circ} \mathrm{C}$ with $0.16 \mathrm{~Hz}$ and $0.05 \%$ strain. The strain sweeps were measured at $1 \mathrm{~Hz}$ and $30^{\circ} \mathrm{C}$. The stress relaxation measurement using the torsion rectangular fixture was carried out at $30^{\circ} \mathrm{C}$ and $10 \%$ strain.

\section{Results and Discussion}

\subsection{Immobilization of Polymer Chains by Crosslinks}

The unique feature of rubber is crosslink, which limits the sliding of polymer chains during deformation, increases its strength at higher extension ratios, and retains its ability to recover upon the removal of deforming forces. During the process of compression molding at $150{ }^{\circ} \mathrm{C}$, sulfur reacts with double bonds in rubber with the aid of an accelerator, sulfonamide, to form sulfur crosslinks between polymer chains. Upon swollen in a good solvent and reached an equilibrium swelling controlled by the presence of crosslinks, the crosslink density of the composites can be estimated by Flory-Rehner equation by assuming the crosslink points are tetrafunctional. The equation is $-\left[\ln \left(1-v_{2}\right)+v_{2}+\right.$ 
$\left.\chi v_{2}{ }^{2}\right]=n V_{1}\left(v_{2}{ }^{1 / 3}-v_{2} / 2\right)$, where the rubber volume fraction in a swollen crosslinked rubber is $v_{2}$. For rubber composites reinforced with filler, $v_{2}$ is the rubber volume fraction after the correction of filler volume. $n$ is the crosslink density defined as the number of network chains between crosslinks. $V_{1}$ (molar volume of toluene) is $106.3 \mathrm{~mole} / \mathrm{cm}^{3} . x$ is interaction parameter for the interaction between toluene and rubber. $\chi$ is 0.36 for NR and toluene [32]. It is shown in Figure 1a that the crosslink density decreased as the amount of calcium carbonate increased for both coated and uncoated calcium carbonates except the composites without protein particles. At low protein concentration, $20 \%$ protein and $80 \%$ calcium carbonate, the protein interferes with the interaction between calcium carbonate and rubber, which results a lower crosslink density than the composites with calcium carbonate only. For unfilled rubbers, effective crosslinks include both chemical crosslinks and polymer entanglements. For filled rubbers, effective crosslinks also include filler-rubber interactions that function as physical junctions. Natural rubber also contains $1-2 \%$ of natural rubber protein. Uncoated calcium carbonate interacts with rubber through natural rubber protein, while the stearic acid coated calcium carbonate interacts with hydrophobic rubber through hydrophobic hydrocarbon tail of stearic acid. Soy protein interacts with natural rubber through natural rubber protein. Such hydrophilic association does not dissociate in hydrophobic toluene. Figure 1 shows that the composites with calcium carbonate have greater crosslink densities than that with stearic acid coated calcium carbonate. This indicates that, in toluene, the interactions between rubber and coated calcium carbonate dissociate easier than that between hydrophilic association of uncoated calcium carbonate and rubber. This can be explained by the interaction between stearic acid coated calcium carbonate and rubber. After the surface of calcium carbonate is coated with stearic acid, calcium carbonate surface becomes hydrophobic and the interaction between the coating and rubber is van der Waals force that is easily dissociated in toluene. This explanation is confirmed by a bound rubber measurement on aged uncured compounds in toluene, where bound rubber for the Ca sample is $94.6 \%$ and for the CS sample is $93.5 \%$. Although aged uncured compound stored at room temperature have a certain degree of crosslinks, the difference between the two samples can still be detected. This swelling study reveals the nature of interface on the surface of the coated and uncoated calcium carbonates. However, toluene changed the filler-rubber interactions. The crosslink density measured by the swelling method is not the effective crosslink density in dry state and cannot be used to explain the mechanical properties in dry state. Nonetheless, the effective crosslink density of dry rubber can be estimated by using plateau modulus from temperature dependent storage modulus at $25^{\circ} \mathrm{C}$ and is shown in Figure $1 \mathrm{~b}$. In a dry state, the rubbers with coated calcium carbonate had higher crosslink densities than that of the rubbers containing uncoated calcium carbonate. The effective crosslink density in dry rubbers can be correlated to the mechanical properties of these rubbers.

In the dry state, the effect of effective crosslinks is different. Figure 2 shows the decrease of reinforcement factor with increasing concentration of calcium carbonate. For unfilled rubber, shear modulus is proportional to crosslink density based on classical theory, $G_{N}^{0}=v k T$, where $v$ is crosslink density, $k$ is Boltzmann constant and $T$ is temperature [33]. For filled rubber, effective crosslink density is defined by the presence of chemical crosslinks, polymer entanglement and filler-rubber interactions that do not dissociate under the strain of the measurement. Figure 2 also shows that coated calcium carbonate has a greater reinforcement effect than uncoated calcium carbonate. 

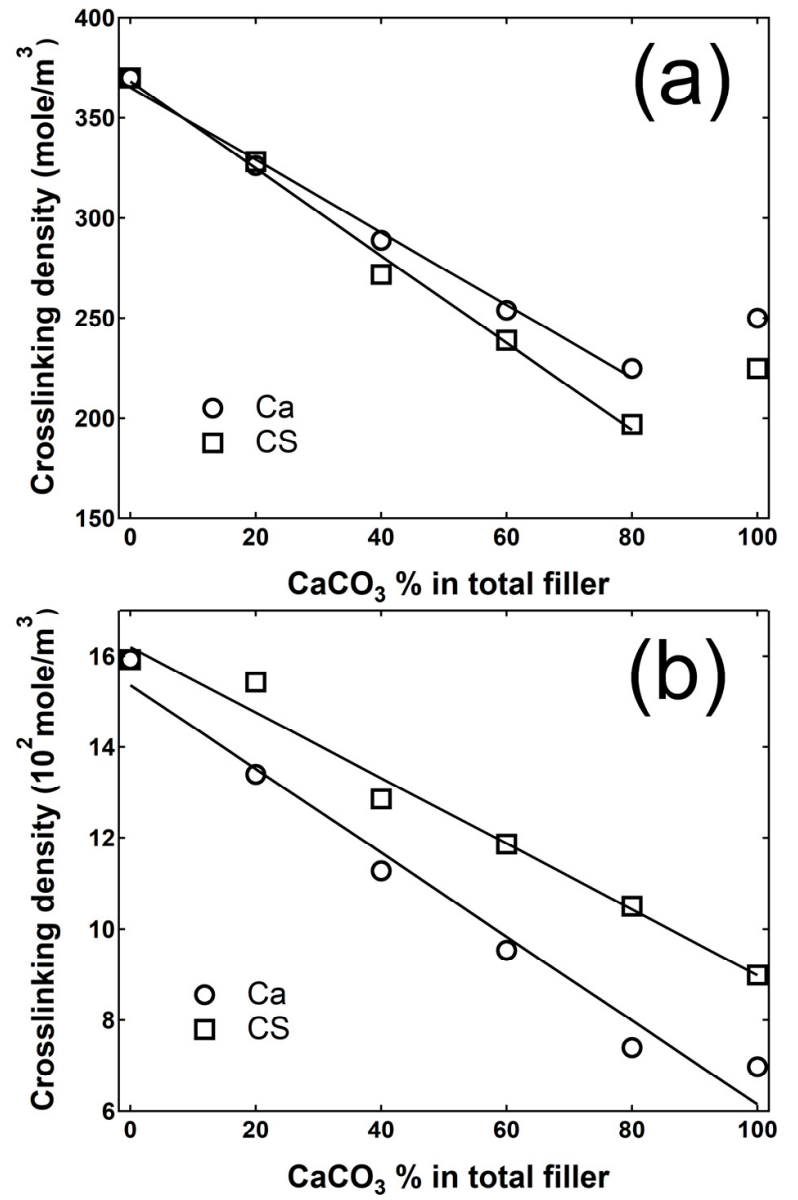

Figure 1. Crosslink densities of protein and calcium carbonate reinforced NR (natural rubber) with 50 phr filler. (a) Swelling method. (b) Plateau moduli method.

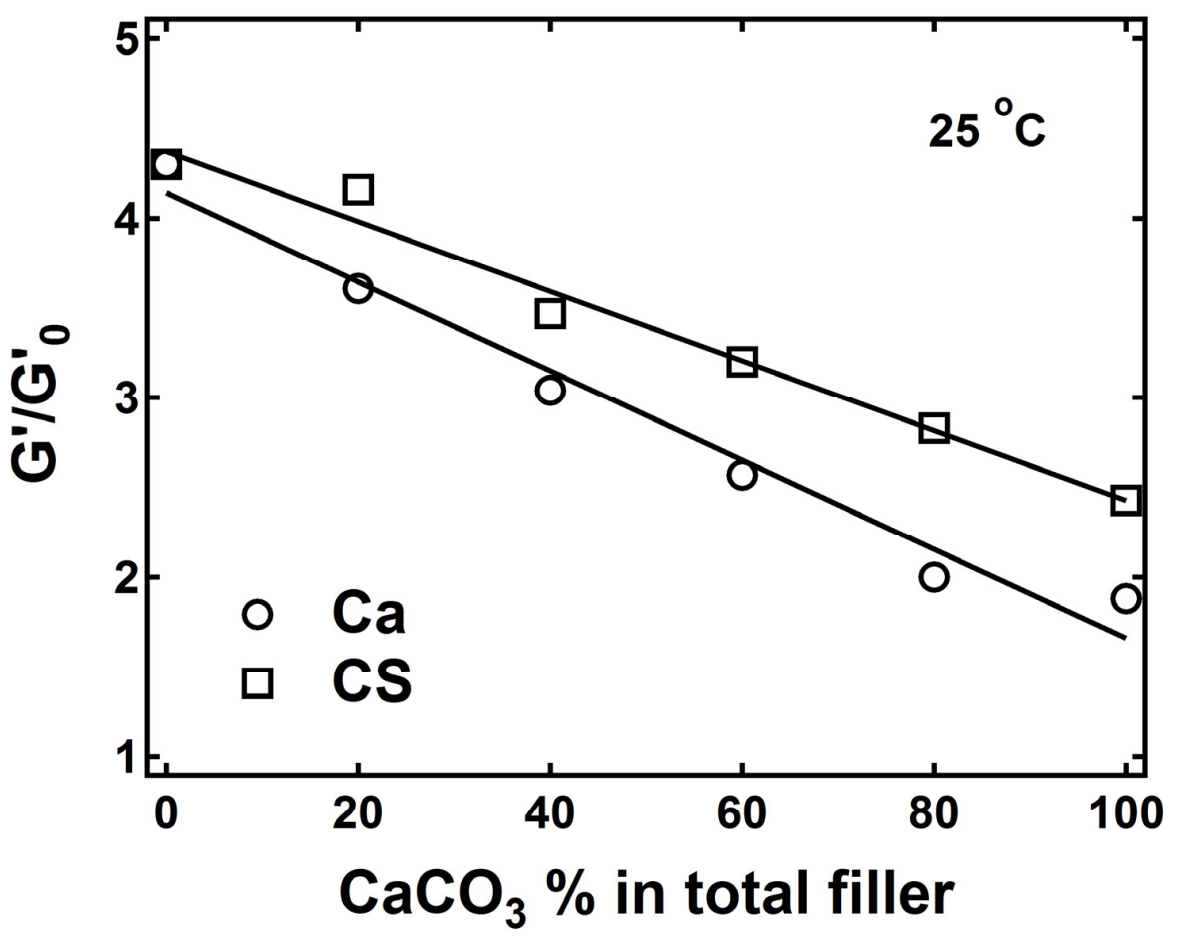

Figure 2. Reinforcement factors of protein and calcium carbonate reinforced NR with 50 phr filler. 
Based on this understanding, it can be concluded that the calcium carbonate particles either coated or uncoated reduce the overall extent of interactions between protein and natural rubber. Both $G^{\prime \prime}$ and $\tan \delta$ of the composites (Figure 3) show that calcium carbonate composite has the greatest amount of mechanical loss as heat and the protein composite has the least amount of loss. The magnitude of loss decreases as the amount of protein increases in the composites, a reflection of higher effective crosslink density in the protein composite. The glass transition temperatures determined from $G^{\prime \prime}$ and $\tan \delta$ are also shown in Figure 3. As $T_{g}$ is related to mobility of polymer chains, the chemical crosslinks from vulcanization and physical crosslinks from filler-polymer interactions can influence $T_{g}$. The shifting of $\mathrm{T}_{\mathrm{g}}$ is then determined by the total crosslink density from both chemical and physical crosslinks. The chemical crosslink density can be measured with swelling method. On the other hand, physical crosslinks cannot be easily isolated and measured. The difference of $T_{g}$ between different composites is within one degree, indicating the changes in their total crosslink densities are small. It does, however, show a tendency of decreased total crosslinks from both chemical and physical immobilization of polymer chains when the protein was added to the calcium carbonate composites at 20/5 and $40 \%$ level, because their glass transition temperatures shifted to a lower temperature.
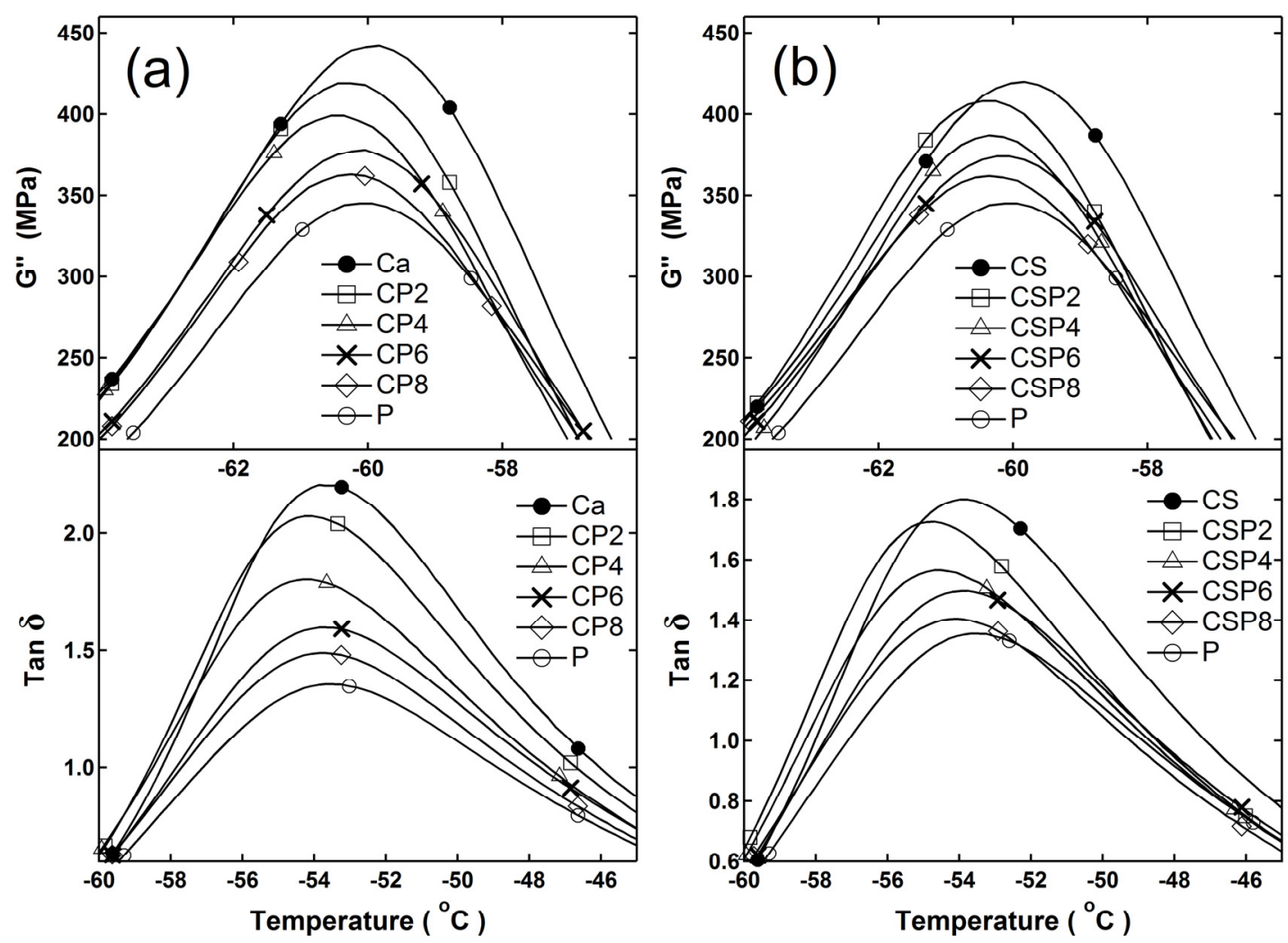

Figure 3. Loss moduli and loss tangent for modified and unmodified rubber composite. (a) $\mathrm{CaCO}_{3}$. (b) $\mathrm{CaCO}_{3}$ modified with stearic acid.

\subsection{Mechanical Properties}

Figure 4 shows the tensile properties of rubber composites with both coated and uncoated calcium carbonates. Protein reinforced composites have higher modulus and lower elongation at break, while the composites reinforced with calcium carbonate particles have higher tensile strength, higher elongation and lower modulus. For both coated and uncoated calcium carbonate composites, Young's modulus, $100 \%$ modulus, and 300\% modulus increase with increasing protein content in the composites. Both tensile strength and elongation at break were improved when $20 \%$ of calcium carbonate was replaced by protein. Such improvement showed a synergistic effect from the inclusion of protein particles in calcium carbonate composites. The maximum tensile strength is 23 and $23.3 \mathrm{MPa}$ 
for uncoated and coated calcium carbonate composites with $20 \%$ protein, respectively. The important numerical values for Figure 4 are listed in Table 2. The tensile properties of unfilled NR are also listed in Table 2. The unfilled NR had low moduli, but the moduli increased significantly with filler reinforcement. The tensile strength of this aged NR is low (Figure 4a), but the same NR was used for all samples. The inclusion of filler significantly increases the tensile strength and moduli. Although fresh NR with low crosslink density can have high tensile strength, it cannot have high value of $300 \%$ modulus without filler reinforcement. The most significant effect of a useful filler is the ability to retain high tensile strength and simultaneously increase 300\% modulus significantly. The inherent nature of low modulus in the composites from the use of calcium carbonate particles is significantly improved by partially replacing calcium carbonate with protein without sacrificing the tensile strength. For practical applications, the ability to adjust mechanical properties by varying the ratio of calcium carbonate and protein to meet the requirements of different applications is very useful. The results also show that the composites with stearic acid coated calcium carbonate have better tensile strength and elongation at break than the composites with uncoated calcium carbonate. Figure 5 shows the comparison of calcium carbonate composites to silica composites. The composites CP6 and CSP6 have tensile properties similar to that of the silica composite without DPG, while the tensile properties of CSP8 is similar to that of the silica composite with DPG. For rubber hardness, it can be represented by Durometer unit or Young's modulus, as shown in Table 3. Both CSP6 and CSP8 have hardness slightly lower than that of the silica composite with DPG. For tear strength shown in Table 3, the silica composites have fewer defects for tear propagation than CSP6 and CSP8 composites.

Figure 4 also shows that calcium carbonate and protein as filler behaved differently in rubber composites at high strain. The different shape of stress-strain curves can be more clearly seen in Figure 6 plotted as reduced stress $\left[\sigma^{*}\right]=\sigma /\left(\lambda-\lambda^{-2}\right)$ against the reciprocal of the extension ratio. This plot came from the Mooney-Rivlin's description of stress-strain relationship [34], $\sigma^{*}=2 C_{1}+2 C_{2} \lambda^{-1}$ with strain independent constants, $2 C_{1}$ and $2 C_{2}$. The upturns of stress-strain curves at higher elongation ratios can be more clearly seen in such plot. The plot also gives a better resolution of the initial moduli of different composites in the small strain region. The unfilled NR shows an upturn and is known to be associated with stress-induced crystallization $[35,36]$. At higher strain, protein composite shows yield behavior, indicating an inhomogeneous particle network structure, where the dissociation of particle network is at softer regions that contain more rubber and less protein particles and is not as rigid as other regions. This yield behavior shows that tensile strength does not increase proportionally as the strain increases. Such yield behavior is not observed in the composites reinforced with calcium carbonate. When the composites include $40 \%$ calcium carbonate particles, the yield behavior is no longer observable, indicating the protein particles were sufficiently diluted when the protein/rubber mixture was prepared in water. With less protein particles in the aqueous latex mixture, its tendency to coagulate into larger particles is decreased when water is removed. The outcome is that the overall homogeneity of the protein containing composites is improved, and therefore its tensile strength. 

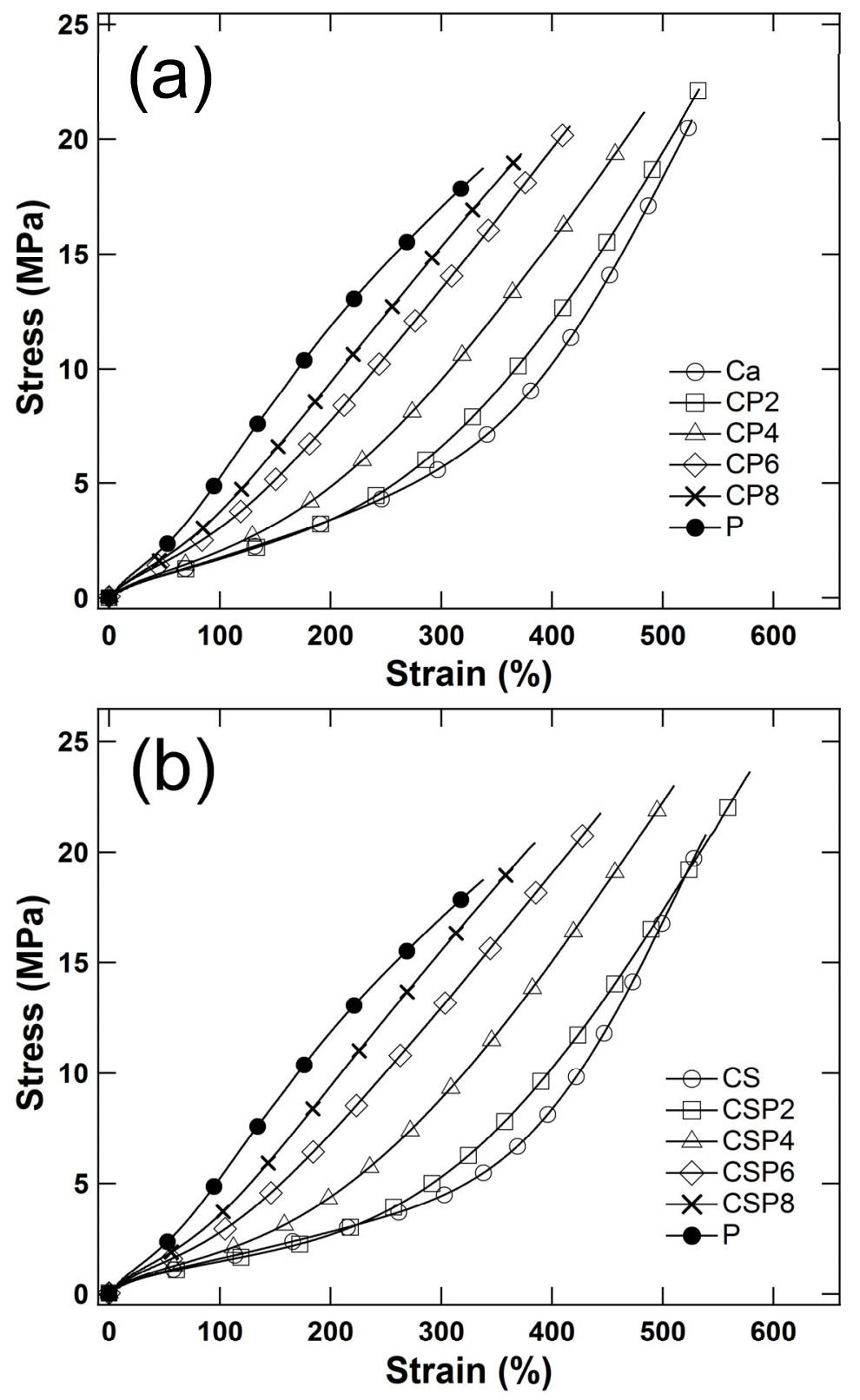

Figure 4. Tensile properties of rubber composites. (a) $\mathrm{CaCO}_{3}$. (b) $\mathrm{CaCO}_{3}$ modified with stearic acid.

Table 2. Tensile Properties.

\begin{tabular}{cccccc}
\hline & $\begin{array}{c}\text { Tensile } \\
\text { Strength } \\
\mathbf{( M P a )}\end{array}$ & $\begin{array}{c}\text { Elongation } \\
\text { at Break } \\
\mathbf{( \% )}\end{array}$ & $\begin{array}{c}\text { Young's } \\
\text { Modulus } \\
\mathbf{( M P a )}\end{array}$ & $\begin{array}{c}\mathbf{1 0 0 \%} \\
\text { Modulus } \\
\mathbf{( M P a )}\end{array}$ & $\begin{array}{c}\mathbf{3 0 0 \%} \\
\text { Modulus } \\
\mathbf{( M P a )}\end{array}$ \\
\hline $\mathrm{NR}$ & $12.1 \pm 1.5$ & $487 \pm 18$ & $1.46 \pm 0.09$ & $1.06 \pm 0.01$ & $2.94 \pm 0.03$ \\
$\mathrm{Ca}$ & $20.4 \pm 0.8$ & $525 \pm 15$ & $2.65 \pm 0.09$ & $1.73 \pm 0.10$ & $5.62 \pm 0.27$ \\
$\mathrm{CP} 2$ & $23.0 \pm 1.1$ & $541 \pm 9$ & $2.70 \pm 0.12$ & $1.72 \pm 0.05$ & $6.67 \pm 0.23$ \\
$\mathrm{CP} 4$ & $21.5 \pm 0.5$ & $477 \pm 12$ & $3.16 \pm 0.18$ & $2.14 \pm 0.07$ & $9.95 \pm 0.29$ \\
$\mathrm{CP6}$ & $20.6 \pm 0.3$ & $423 \pm 13$ & $4.13 \pm 0.15$ & $2.99 \pm 0.15$ & $13.27 \pm 0.43$ \\
$\mathrm{CP} 8$ & $19.3 \pm 0.3$ & $376 \pm 8$ & $4.55 \pm 0.17$ & $3.71 \pm 0.11$ & $15.12 \pm 0.29$ \\
$\mathrm{P}$ & $18.4 \pm 0.8$ & $333 \pm 17$ & $5.52 \pm 0.06$ & $5.14 \pm 0.11$ & $16.95 \pm 0.16$ \\
\hline
\end{tabular}


Table 2. Cont.

\begin{tabular}{|c|c|c|c|c|c|}
\hline & $\begin{array}{c}\text { Tensile } \\
\text { Strength } \\
\text { (MPa) }\end{array}$ & $\begin{array}{c}\text { Elongation } \\
\text { at Break } \\
(\%)\end{array}$ & $\begin{array}{l}\text { Young's } \\
\text { Modulus } \\
\text { (MPa) }\end{array}$ & $\begin{array}{c}100 \% \\
\text { Modulus } \\
\text { (MPa) }\end{array}$ & $\begin{array}{c}300 \% \\
\text { Modulus } \\
\text { (MPa) }\end{array}$ \\
\hline CS & $20.3 \pm 1.1$ & $530 \pm 14$ & $3.05 \pm 0.08$ & $1.62 \pm 0.04$ & $4.54 \pm 0.17$ \\
\hline CSP2 & $23.3 \pm 0.8$ & $573 \pm 14$ & $3.05 \pm 0.13$ & $1.47 \pm 0.03$ & $5.27 \pm 0.21$ \\
\hline CSP4 & $23.1 \pm 0.5$ & $516 \pm 4$ & $3.47 \pm 0.07$ & $1.89 \pm 0.06$ & $8.81 \pm 0.28$ \\
\hline CSP6 & $22.3 \pm 1.1$ & $453 \pm 14$ & $4.16 \pm 0.29$ & $2.75 \pm 0.15$ & $12.89 \pm 0.54$ \\
\hline CSP8 & $20.9 \pm 0.6$ & $394 \pm 11$ & $4.79 \pm 0.16$ & $3.69 \pm 0.06$ & $15.60 \pm 0.18$ \\
\hline $\mathrm{Si}$ & $23.9 \pm 0.6$ & $467 \pm 12$ & $3.73 \pm 0.07$ & $2.40 \pm 0.06$ & $12.23 \pm 0.25$ \\
\hline $\mathrm{SiD}$ & $21.9 \pm 0.7$ & $400 \pm 7$ & $5.12 \pm 0.18$ & $3.34 \pm 0.13$ & $14.74 \pm 0.24$ \\
\hline
\end{tabular}

All rubbers have 50 phr total filler. $\mathrm{Si}=$ silica reinforced rubber. $\mathrm{SiD}=$ silica reinforced rubber with $1 \mathrm{phr}$ DPG (1.3-diphenylguanidine).

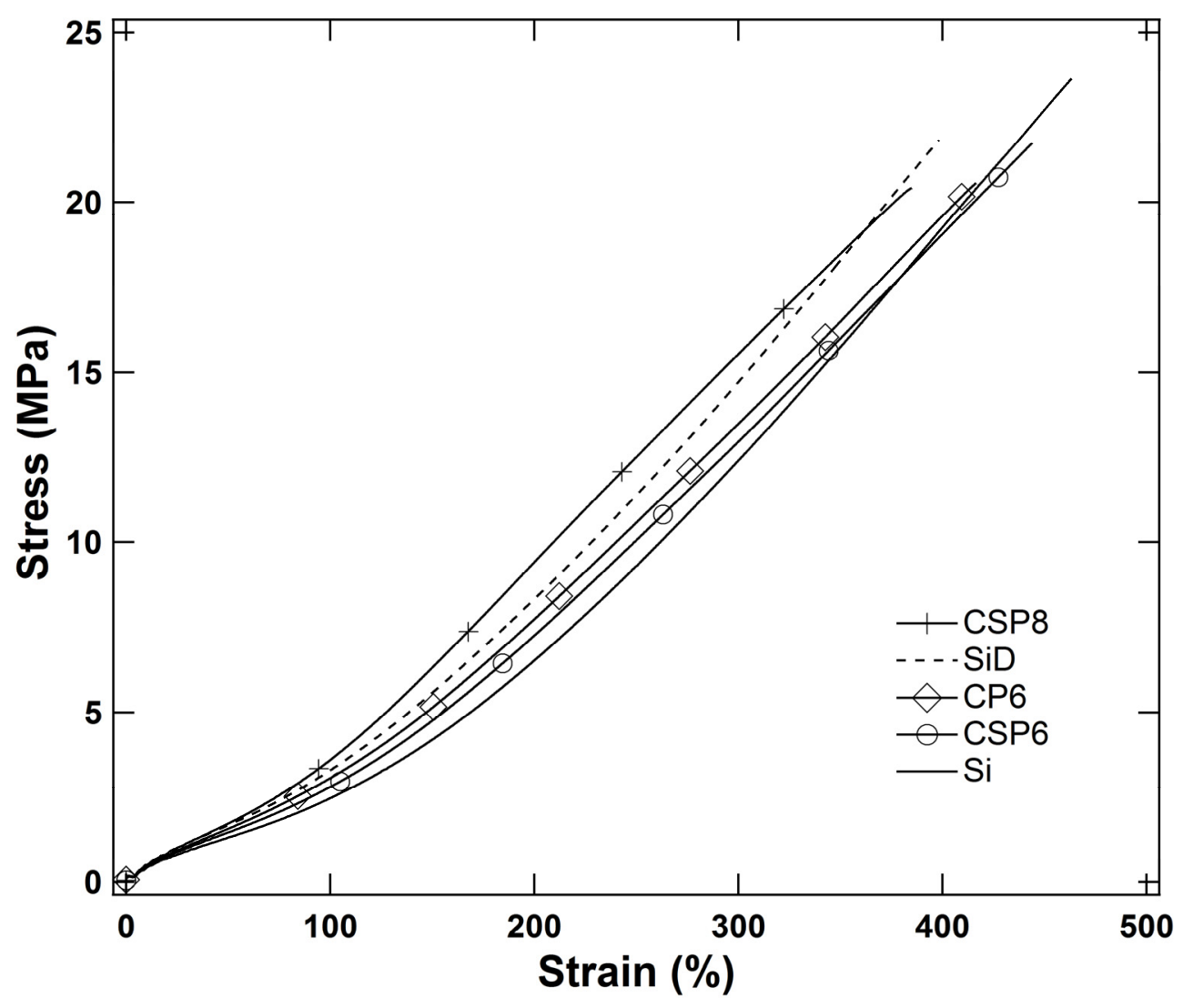

Figure 5. Tensile properties of rubber composites. $\mathrm{Si}=$ silica reinforced composite. $\mathrm{SiD}=$ silica reinforced composite with 1 phr DPG (1.3-diphenylguanidine).

Table 3. Hardness and tear resistance.

\begin{tabular}{cccc}
\hline & $\begin{array}{c}\text { Hardness } \\
\text { (Shore A) }\end{array}$ & $\begin{array}{c}\text { Young's Modulus } \\
\mathbf{( M P a )}\end{array}$ & $\begin{array}{c}\text { Tear Strength } \\
\mathbf{( N / m m )}\end{array}$ \\
\hline CSP6 & 67 & $4.16 \pm 0.29$ & $9.0 \pm 1.3$ \\
$\mathrm{CSP} 8$ & 68 & $4.79 \pm 0.16$ & $8.3 \pm 3.2$ \\
\hline $\mathrm{Si}$ & 67 & $3.73 \pm 0.07$ & $15.7 \pm 2.4$ \\
$\mathrm{SiD}$ & 71 & $5.12 \pm 0.18$ & $12.2 \pm 3.2$ \\
\hline
\end{tabular}



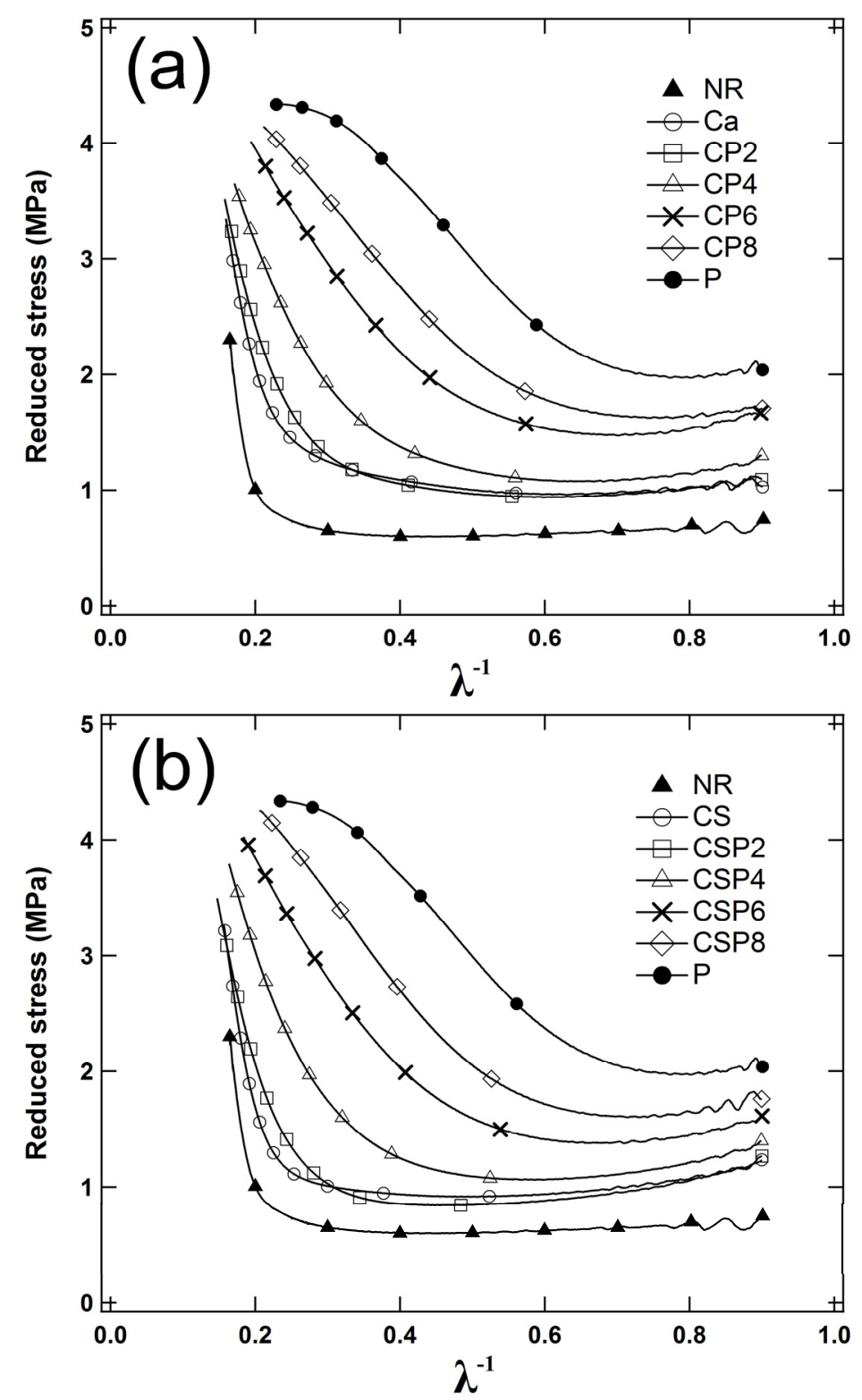

Figure 6. Reduced stress of rubber composites. (a) $\mathrm{CaCO}_{3}$ (b) $\mathrm{CaCO}_{3}$ modified with stearic acid.

For practical applications, Table 2 shows that the composites with more than $40 \%$ of calcium carbonate replaced by protein particles have tensile strength, elongation, and modulus values to meet the requirements of many rubber applications including various molded rubber components. The silica reinforced composite is also included in Table 2 for comparison. The composite CSP6 that contains $60 \%$ protein and $40 \%$ coated calcium carbonate has mechanical properties that are similar to that of the silica reinforced composites. The silica reinforced rubbers have been used in tires to reduce rolling resistance, which saves energy. Thus, the current components of protein and calcium carbonate have potential to be used in the formulation of rubber composites for tire applications. Figure 7 shows that G' of CSP6 had a higher elastic modulus in the rubber plateau region, but had a slightly lower modulus in the glassy region. This is explained as the segmental motion in silica reinforced rubber was more restricted by coupling reactions at the interface of silica and rubber. On the other hand, CSP6 had a greater effect on the restriction of polymer chains at the higher temperature region (rubber plateau region). This is explained as the effect of protein nanoparticles that can associate with each other through strong ionic and hydrogen bonds form a more rigid particle network that can hinder the vibrational motion of the polymer chains, similar to the presence of a flexible rope around a rigid steel rod. The concept is best 
described by the existing tube model, where the polymer motion is restricted simply by the presence of other rigid obstacles around the polymer chains, and does not necessarily require a strong coupling reaction between the fillers and polymer chains. For tire applications, rolling resistance is an important property that defines how much energy is saved when a tire is rotating. The $\tan \delta$ at $60^{\circ} \mathrm{C}$ has been used to predict rolling resistance of rubber composites. The lower the $\tan \delta$ at $60^{\circ} \mathrm{C}$, the lower the rolling resistance and more energy is saved. The change of $\tan \delta$ at $60^{\circ} \mathrm{C}$ with increasing amount of protein particles is shown in Figure 8. It shows that $\tan \delta$ decreases with increasing protein content for stearic acid coated calcium carbonate composites, while it increases with increasing protein content in uncoated calcium carbonate composites. These $\tan \delta$ values can be compared to silica composites with silane coupling agent, prepared with the same rubber formulation and under the same processing conditions. Silica rubber composite has less rolling resistance than carbon black composites, and is an industrial standard for low rolling resistance tires. The tan $\delta$ at $60^{\circ} \mathrm{C}$ for the silica composite is $\sim 0.026$, which is similar to that of CSP6. This indicates the calcium carbonate and protein nanoparticles can be used as components in rubber composites to reduce rolling resistance. The rubber composite CP6 has an even lower $\tan \delta$ of $\sim 0.017$ and has similar tensile properties as that of silica reinforced rubber. For higher temperature applications, the highly hydrolyzed protein filler has a lot of ionic functional groups to form ionic crosslinks within the particles and is stable up to $200{ }^{\circ} \mathrm{C}$ without degradation, as shown in a previous thermal degradation study [37]. The highly hydrolyzed protein is totally denatured, and is not subjected to bacteria degradation under high $\mathrm{pH}$, especially as rubber encapsulated fillers.

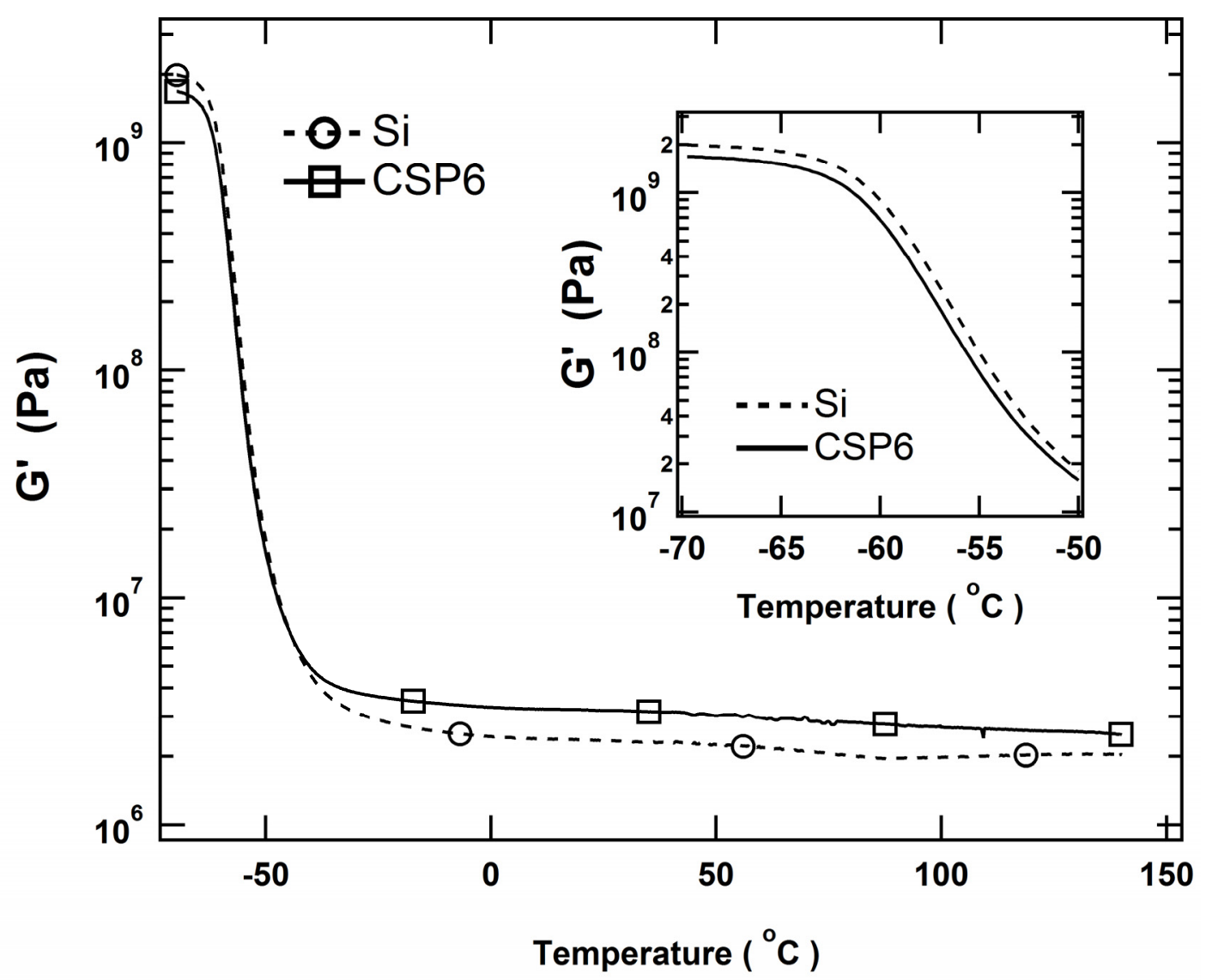

Figure 7. $\mathrm{G}^{\prime}$ of silica reinforced rubber and protein/ $\mathrm{CaCO}_{3}$ reinforced rubber. 


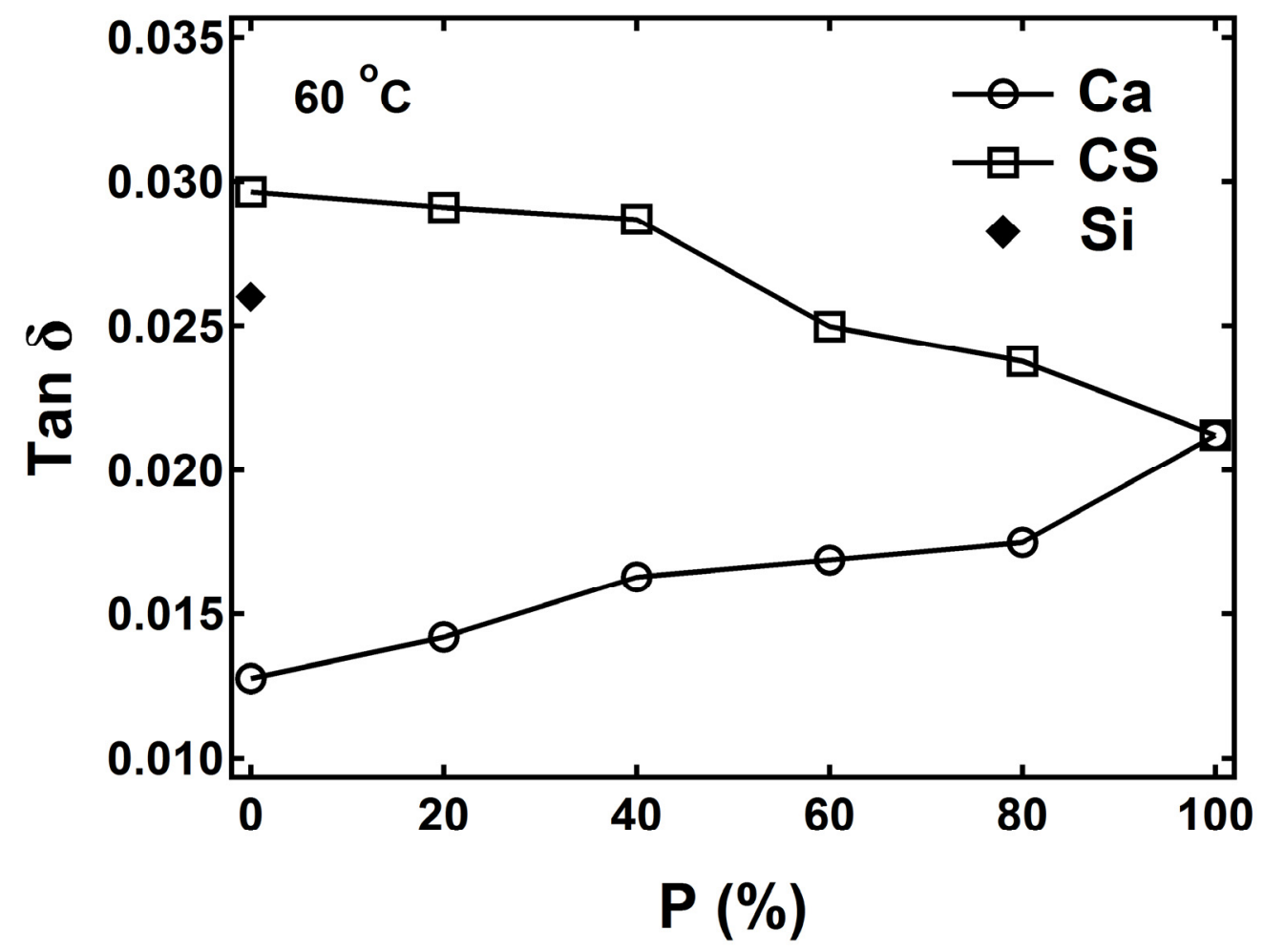

Figure 8. Loss tangent at $60^{\circ} \mathrm{C}$ as predictive performance of rolling resistance.

Figure 9 shows the strain dependent elastic moduli of rubbers. The curves are interpreted using Kraus model, $\left(G^{\prime}(\gamma)-G_{\infty}^{\prime}\right) /\left(G_{0}^{\prime}-G_{\infty}^{\prime}\right)=1 /\left[1+\left(\gamma / \gamma_{c}\right)^{2 n}\right]$, where $G_{0}^{\prime}$ is equal to $G^{\prime}(\gamma)$ at very small strain, $G_{\infty}^{\prime}$ is equal to $G^{\prime}(\gamma)$ at very large strain, $n$ is a fitting parameter related to filler aggregate structures, where cluster-cluster aggregation model was used to relate $n$ to fractal dimension and minimum path length of a filler aggregate [38], and $\gamma_{c}$ is a characteristic strain where $G_{0}^{\prime}-G_{\infty}^{\prime}$ is reduced to half of its zero-strain value. The fitting of the curves produces $\gamma_{c}$ values shown in Figure 9 . Elastic modulus at the linear viscoelastic region is proportional to the total crosslink density of the rubbers. For flexible rubber composites, the $\gamma_{c}$ value occurs at a larger strain. While, the $\gamma_{c}$ value of a rigid rubber composite occurs at a smaller strain. For silica reinforced rubbers, the rubber that has a higher crosslink density because of the addition of DPG has a $\gamma_{c}$ value of 15 compared to a $\gamma_{c}$ value of 44 for the silica composite without DPG, which has a lower crosslink density. Compared to the silica reinforced rubbers, calcium carbonate/protein reinforced rubbers are more flexible and have higher values of $\gamma_{c}$. 


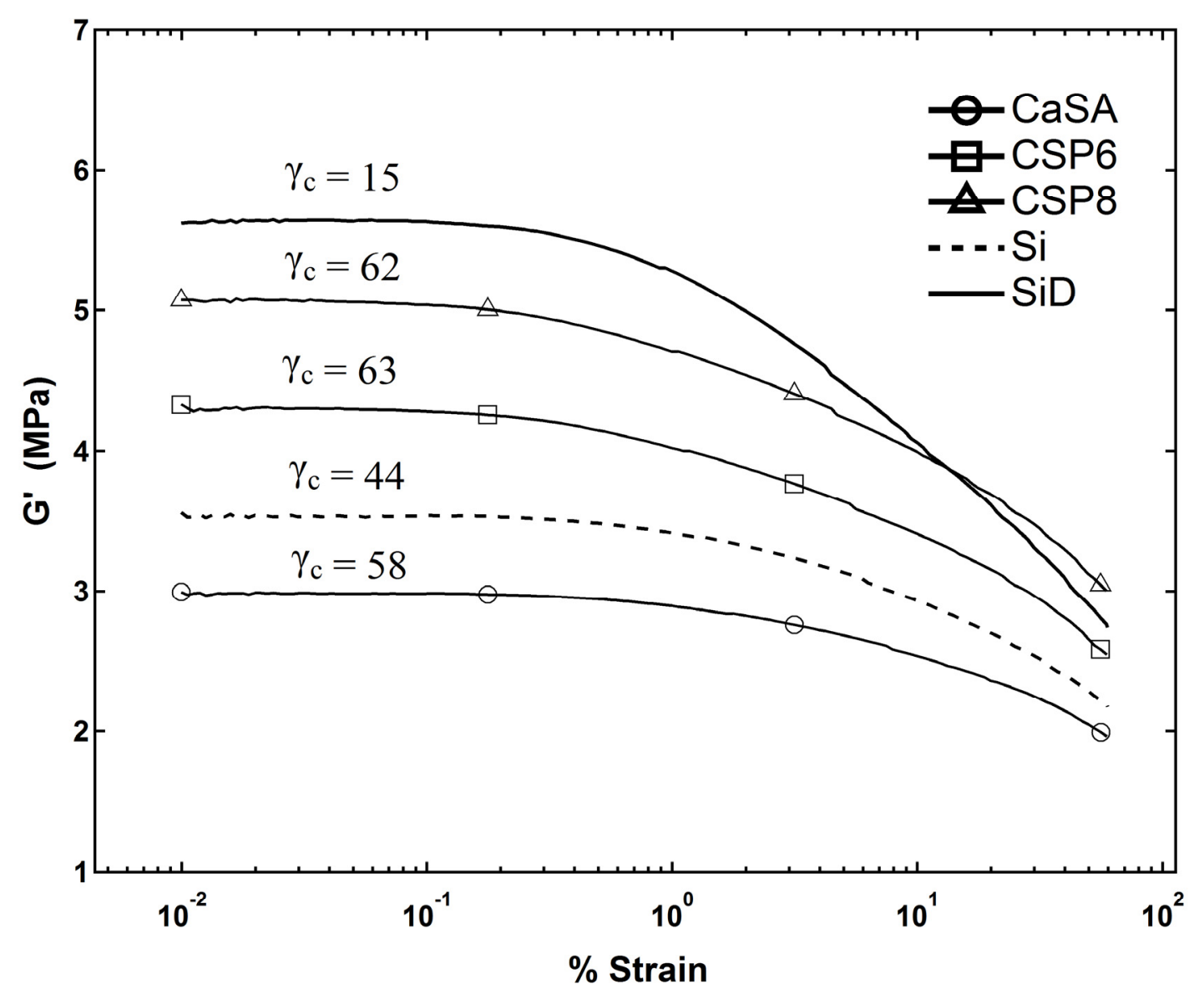

Figure 9. Strain dependent elastic moduli of protein/ $\mathrm{CaCO}$ reinforced rubber compared to silica reinforced rubber.

\subsection{Relaxation and Filler-Polymer Interactions}

The effect of filler-rubber interaction can be observed from Figure 10, where the silica composites with silane coupling agent had a low magnitude broad transition between $30-80{ }^{\circ} \mathrm{C}$ when plotted in logarithmic scale, while silica reinforced rubber without silane coupling agent does not have such transition [37]. Therefore, the transition is related to filler-rubber interactions. G" transition is related to glass transition temperature. Such a broad transition is then related to immobilization of polymers by filler surface. However, such a transition is small and not discernible if the loss tangent is plotted in linear scale. It also needs to have sufficient amount of coupling between the filler and the matrix to exhibit such broad transition. Therefore, it depends on the surface area of the filler, the amount of coupling agent, the number of bonds between filler particles and coupling agent, and the number of bonds between the coupling agent and rubber. The composite CSP6 also has a small and broad transition similar to that of the silica composite. The transition may be explained by Figure 11, where it shows that the small and broad transition appears $\left(20-80^{\circ} \mathrm{C}\right)$ in the loss modulus curve of coated calcium carbonate, but not significant in that of uncoated calcium carbonate. Therefore, the transition appears to come from the filler-rubber interactions. 


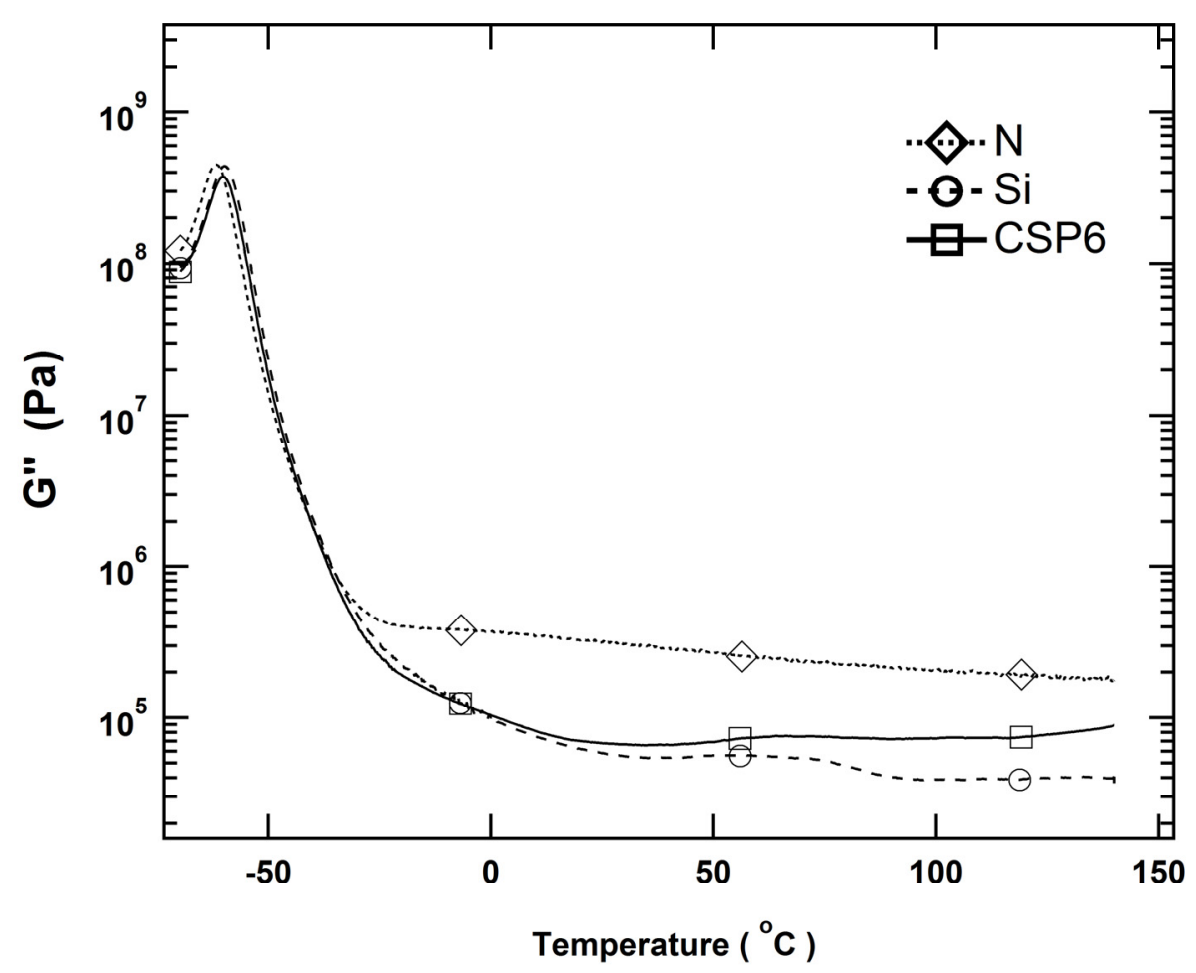

Figure 10. Loss moduli for silica reinforced rubbers and protein/ $\mathrm{CaCO}$ reinforced rubber, where $\mathrm{N}$ is silica without coupling agent and $\mathrm{Si}$ is silica coated with silane coupling agent.

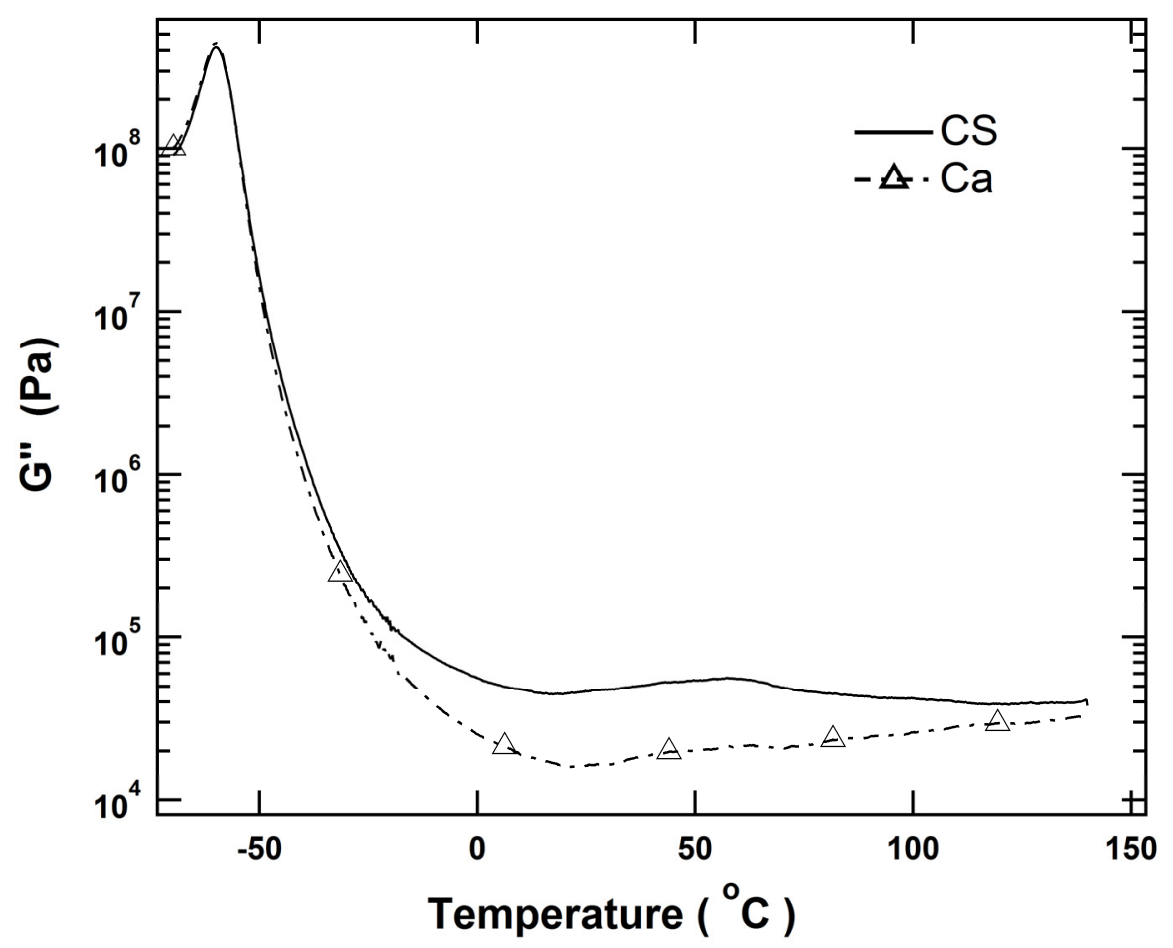

Figure 11. Loss moduli for stearic acid coated and uncoated $\mathrm{CaCO}_{3}$ reinforced rubber at $50 \mathrm{phr}$.

When a rubber composite is subjected to a constant strain, interactions within a composite dissociate over time and are reflected as a decrease of stress. Therefore, stress relaxation can give insight into the nature of interactions in the composites. Figure 12 shows the relaxation behaviors of NR, protein composite, and calcium carbonate composites. For the NR, constrains of polymer chains include sulfur crosslinks and polymer entanglements. NR has a smaller relaxation rate, initially 
because the polymer chains are restrained by strong chemical crosslinks, but takes a longer time to reach equilibrium because the unfolding of polymer entanglements is a slow process. The composite with uncoated calcium carbonate particles has a similar curve shape as that of NR except their equilibrium values, indicating that the relaxation mechanism of uncoated calcium carbonate composite is similar to that of NR, but uncoated calcium carbonate has additional hydrogen bonds with NR protein. These weaker hydrogen bonds can dissociate first and results in slighter greater initial relaxation rate. The composite with protein particles has hydrogen and ionic bonds in addition to covalent bonds. These weaker bonds also dissociate first under strain and result in greater initial relaxation rate, but reach equilibrium faster than NR. Calcium carbonate coated with stearic acid has the greatest initial relaxation rate than NR, protein, and uncoated calcium carbonate composites, because the hydrophobic portion of stearic acid interact with NR through weak Van der Waal forces and can dissociate quickly under stress. The stress relaxation curves of these composites may be fitted with the empirical model of Chasset and Thirion [39], $G(t)=G_{\infty}\left[1+\left(t / \tau_{0}\right)^{-m}\right]$, where $G_{\infty}$ is the equilibrium modulus, $G(t)$ is the isothermal relaxation modulus, and $m$ and $\tau_{o}$ are material properties. The model fitting is shown in Figure 12. The dash lines are the model fit to the experimental data for protein and coated calcium carbonate composites. The experimental data of NR and uncoated calcium carbonate composites cannot be fitted with this model because they have not reached the equilibrium values within the time frame measured. The parameters used in the model fit is tabulated in Table 4 , where $\tau_{0}$ is significantly different between protein and coated calcium carbonate composites, indicating a significant difference between their material properties. A theoretical basis for the empirical model has been provided by Curro and Pincus [40], who relate $m$ and $\tau_{o}$ to the crosslink density of crosslinked natural rubber without filler. For filled NR, the effective crosslink density in the dry state includes both covalent bonds and non-covalent bonds. The covalent bonds are from the sulfur crosslinks and the non-covalent bonds include filler-rubber and filler-filler interactions through ionic bonds, hydrogen bonds and Van der Waals forces. For the composites with both protein and calcium carbonate particles, the data can be reasonably fitted with the model (Figure 13). The fitting parameters (Table 4) for these composites have a greater similarity to that of the protein composite, indicating the protein particles have a significant influence on the relaxation behavior of these composites. For uncoated calcium carbonate composites, the initial relaxation rate shows a trend that decreases with increasing protein content, reflecting the increasing number of weaker non-covalent bonds in the composites. For coated calcium carbonate composites, their $G_{\infty}$ values are lower than that of uncoated calcium carbonate composites, reflecting the influence of the relaxation behavior of the steric acid coated calcium carbonate composite. As the composite with coated calcium carbonate particles (CS) has a greater relaxation rate than that of the protein composite $(\mathrm{P})$, the increase in the protein content decreases the initial relaxation rate (Figure 12) except the composite with $80 \%$ protein and $20 \%$ coated calcium carbonate, which is similar to the composites with $60 \%$ protein and $40 \%$ coated calcium carbonate. The material properties characterized by $m$ and $\tau_{0}$, related to effective crosslinking density, listed in Table 4 , also show that the relaxation behaviors of coated and uncoated calcium carbonate composites are different.

Table 4. Stress relaxation fitting parameters.

\begin{tabular}{cccc}
\hline & $\boldsymbol{G}_{\infty}$ & $\boldsymbol{\tau}_{\boldsymbol{o}}$ & $\boldsymbol{m}$ \\
\hline $\mathrm{P}$ & 0.4912 & 0.4 & 0.045 \\
$\mathrm{CS}$ & 0.4345 & 40 & 0.057 \\
\hline $\mathrm{CP} 2$ & 0.4967 & 0.4 & 0.0375 \\
$\mathrm{CP} 4$ & 0.4958 & 0.4 & 0.040 \\
$\mathrm{CP6}$ & 0.4954 & 0.4 & 0.041 \\
$\mathrm{CP} 8$ & 0.4927 & 0.4 & 0.0465 \\
\hline $\mathrm{CSP} 2$ & 0.4853 & 0.8 & 0.066 \\
$\mathrm{CSP} 4$ & 0.4867 & 0.8 & 0.052 \\
$\mathrm{CSP} 6$ & 0.4871 & 0.8 & 0.047 \\
$\mathrm{CSP} 8$ & 0.4858 & 0.8 & 0.048 \\
\hline
\end{tabular}




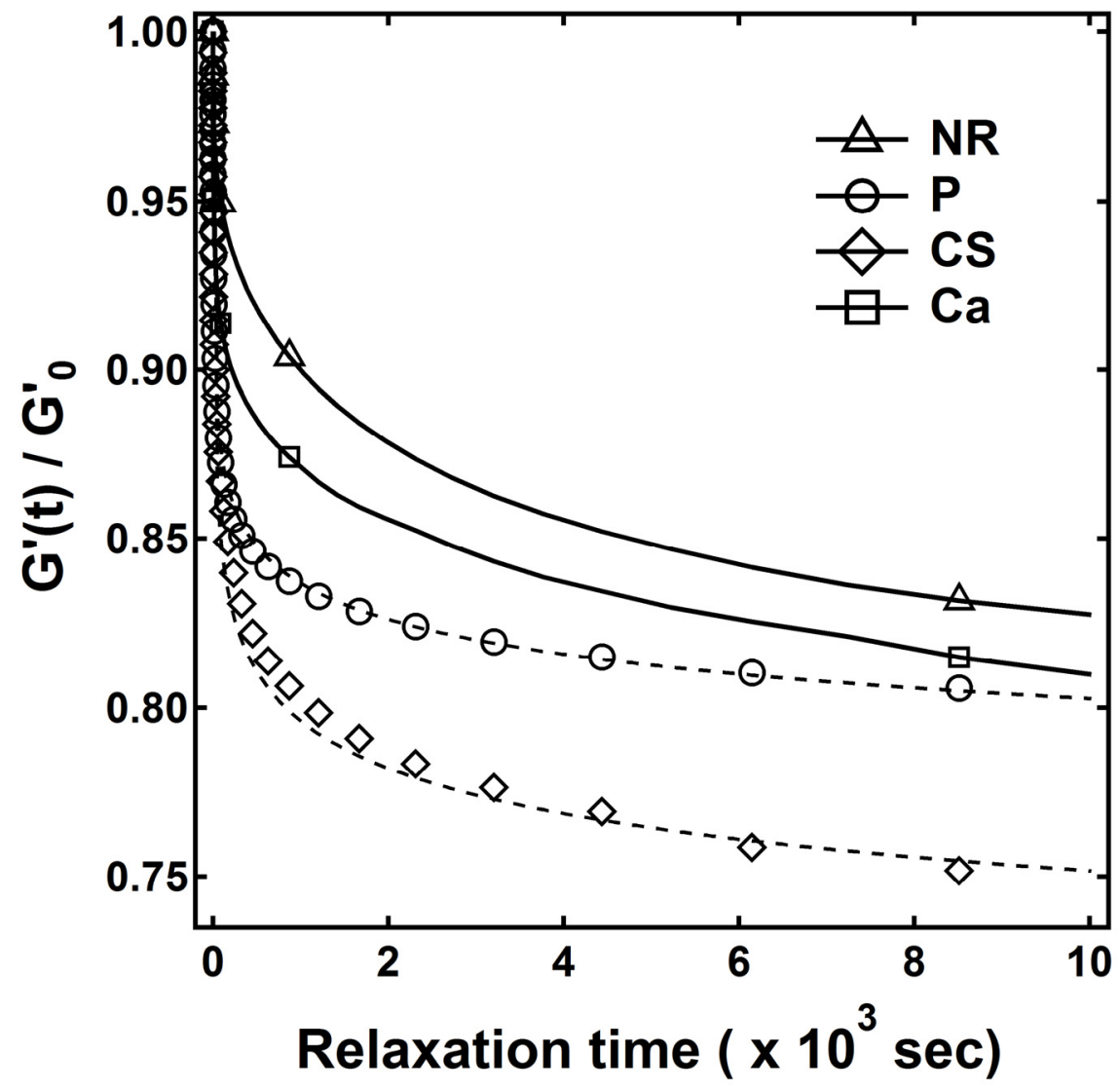

Figure 12. Stress relaxation moduli at $30{ }^{\circ} \mathrm{C}$ and $10 \%$ strain. Dash lines are the model fit.

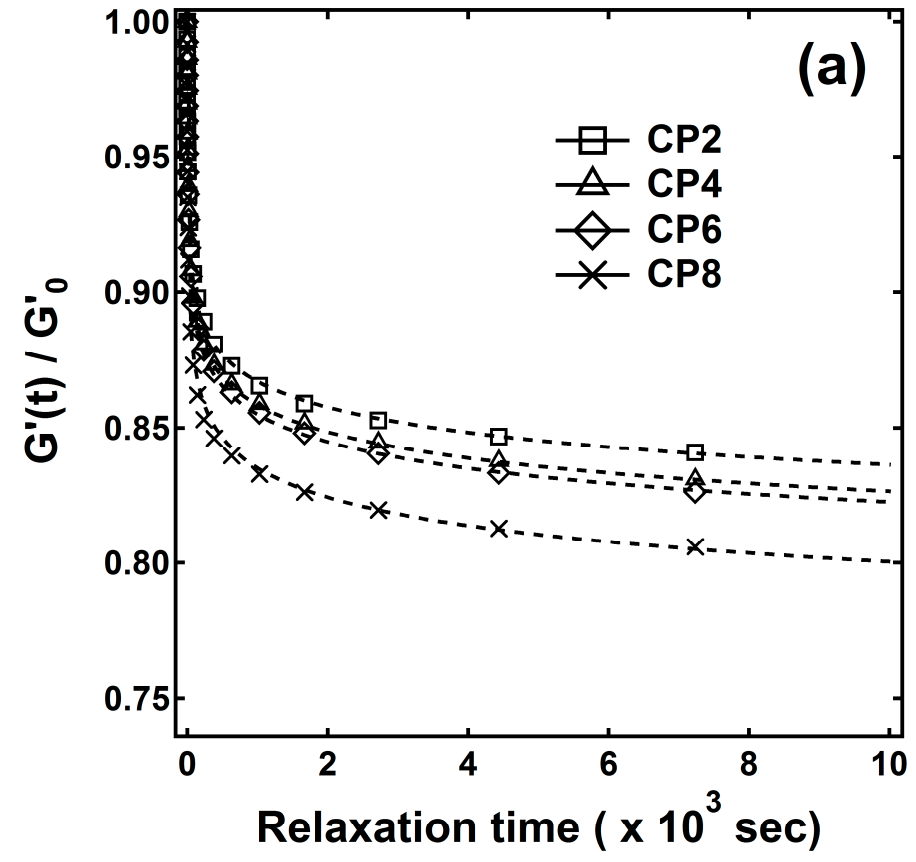

Figure 13. Cont. 


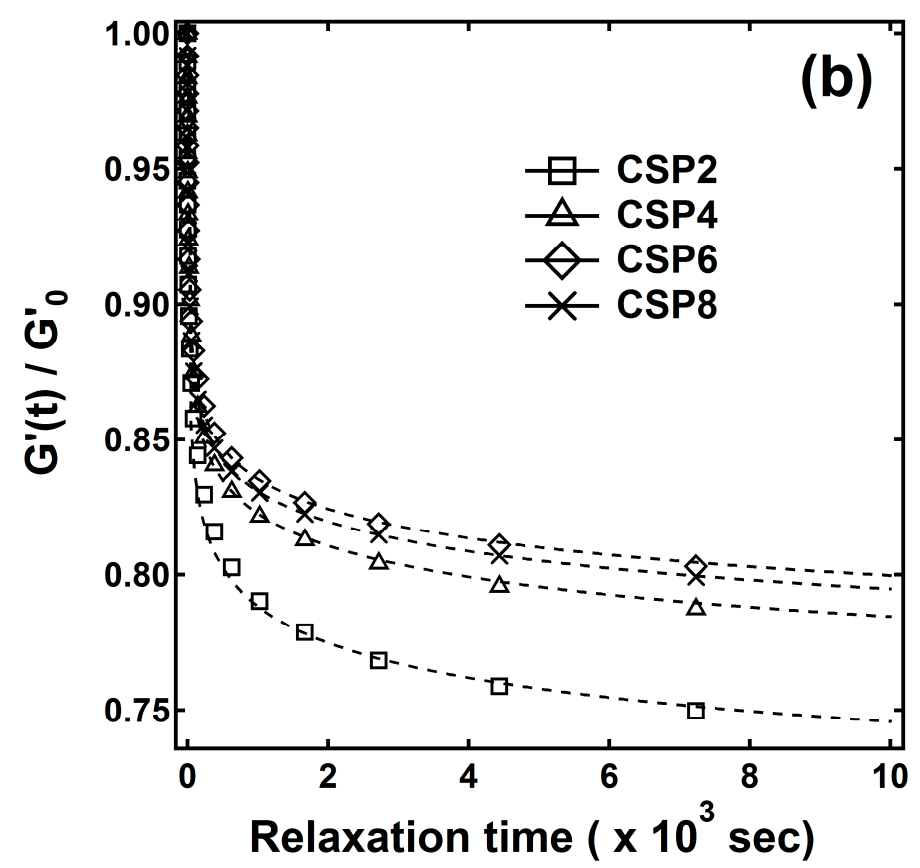

Figure 13. Stress relaxation moduli at $30{ }^{\circ} \mathrm{C}$ and $10 \%$ strain. (a) $\mathrm{CaCO}_{3}$. (b) $\mathrm{CaCO}_{3}$ modified with stearic acid. Dash lines are the model fit.

\section{Conclusions}

Mechanical properties of rubber composites reinforced with calcium carbonate particles are significantly improved by partially replacing calcium carbonate particles with soy protein nanoparticles. The study of crosslink density shows that the addition of protein increases the effective crosslink density of calcium carbonate composites and is responsible for the increase of modulus. Stearic acid coated calcium carbonate particles have a greater reinforcement effect than the uncoated calcium carbonate particles. Both tensile strength and elongation at break were improved when $20 \%$ of calcium carbonate particles were replaced by protein particles, and it showed a synergistic effect from the inclusion of protein particles in calcium carbonate composites. The resultant mechanical properties from the synergistic effect of calcium carbonate and soy protein have the potential to be used in rubber applications when compared to silica reinforced rubbers. The composites reinforced with both protein and calcium carbonate also have similar or lower rolling resistance than silica reinforced rubber composites for potential use as components in tire tread applications. The stress relaxation behaviors of these composites reveal that protein particles have a significant influence on the relaxation behavior of both coated and uncoated calcium carbonate composites. This development demonstrates an economical method to significantly improve the tensile properties of rubber composites reinforced with calcium carbonate for rubber applications, and with a potential to reduce the cost of silica reinforced rubbers, because both soy protein and calcium carbonate are lower cost materials.

Funding: This research received no external funding.

Conflicts of Interest: The authors declare no conflict of interest.

\section{References}

1. Jiang, L.; Lam, Y.C.; Tam, K.C.; Chua, T.H.; Sim, G.W.; Ang, L.S. Strengthening acrylonitrile-butadiene-styrene (ABS) with nano-sized and micro-sized calcium carbonate. Polymer 2005, 46, 243-252. [CrossRef]

2. He, H.; Zhang, Z.; Wang, J.; Li, K. Compressive properties of nano-calcium carbonate/epoxy and its fiber composites. Compos. Part B 2013, 45, 919-924. [CrossRef]

3. Chan, C.; Wu, J.; Li, J.; Cheung, Y. Polypropylene/calcium carbonate nanocomposites. Polymer 2002, 43, 2981-2992. [CrossRef] 
4. Nascimento, E.M.; Eiras, D.; Pessan, L.A. Effect of thermal treatment on impact resistance and mechanical properties of polypropylene/calcium carbonate nanocomposites. Compos. Part B 2016, 91, 228-234. [CrossRef]

5. Lin, Y.; Chen, H.; Chan, C.; Wu, J. The toughening mechanism of polypropylene/calcium carbonate nanocomposites. Polymer 2010, 51, 3277-3284. [CrossRef]

6. Essabir, H.; Bensalah, M.O.; Rodrigue, D.; Bouhfid, R.; Qaiss, A.E.K. A comparison between bio- and mineral calcium carbonate on the properties of polypropylene composites. Constr. Build. Mater. 2017, 134, 549-555. [CrossRef]

7. Zokaei, S.; Lesan khosh, M.R.; Bagheri, R. Study of scratch resistance in homo- and co-polypropylene filled with nanometric calcium carbonate. Mater. Sci. Eng. A 2007, 445-446, 526-536. [CrossRef]

8. Rungruang, P.; Grady, B.P.; Supapho, P. Surface modified calcium carbonate particles by amicellar polymerization to be used as a filler for isotactic polypropylene. Colloids Surf. A 2006, 275, 114-125. [CrossRef]

9. Cao, Z.; Daly, M.; Clemence, L.; Geever, L.M.; Major, I.; Higginbotham, C.L.; Devine, D.M. Chemical surface modification of calcium carbonate particles with stearic acid using different treating methods. Appl. Surf. Sci. 2016, 378, 320-329. [CrossRef]

10. Bartczak, Z.; Argon, A.S.; Cohen, R.E.; Weinberg, M. Toughness mechanism in semi-crystalline polymer blend: II. High-density polyethylene toughened with calcium carbonate filler particles. Polymer 1999, 40, 2347-2365. [CrossRef]

11. Hu, L.; Dong, P.; Zhen, G. Preparation of active $\mathrm{CaCO}_{3}$ nanoparticles and mechanical properties of the composite materials. Mater. Lett. 2009, 63, 373-375. [CrossRef]

12. Zhao, L.; Zhang, Y.; Miao, Y.; Nie, L. Controlled synthesis, characterization and application of hydrophobic calcium carbonate nanoparticles in PVC. Powder Technol. 2016, 288, 184-190. [CrossRef]

13. Wang, Q.; Zhang, X.; Dong, W.; Gui, H.; Gao, J.; Lai, J.; Liu, Y.; Huang, F.; Song, Z.; Qiao, J. Novel rigid poly(vinyl chloride) ternary nanocomposites containing ultrafine full-vulcanized powdered rubber and untreated nano-sized calcium carbonate. Mater. Lett. 2007, 61, 1174-1177. [CrossRef]

14. Li, X.H.; Tjong, S.C.; Meng, Y.Z.; Zhu, Q.J. Fabrication and properties of poly(propylene carbonate) calcium carbonate composites. Polym. Sci. Part B Polym. Phys. 2003, 41, 1806-1813. [CrossRef]

15. Osman, M.A.; Atallah, A.; Suter, U.W. Influence of excessive filler coating on the tensile properties of LDPE-calcium carbonate composites. Polymer 2004, 45, 1177-1183. [CrossRef]

16. Saad, A.L.; Younan, A.F. Rheological, mechanical and electrical properties of natural rubber-white filler mixtures reinforced with nylon 6 short fibers. Polym. Degrad. Stab. 1995, 50, 133-140. [CrossRef]

17. Poompradub, S.; Ikeda, Y.; Kokubo, Y.; Shiono, T. Cuttlebone as reinforcing filler for natural rubber. Eur. Polym. J. 2008, 44, 4157-4164. [CrossRef]

18. Saeb, M.R.; Ramezani-Dakhel, H.; Ali Khonakdar, H.; Heinrich, G.; Wagenknecht, U. A comparative study on curing characteristics and thermomechanical properties of elastomeric nanocomposites: The effect of eggshell and calcium carbonate nanofillers. J. Appl. Polym. Sci. 2013, 127, 4241-4250. [CrossRef]

19. Poh, B.T.; Ismail, H.; Tan, K.S. Effect of filler loading on tensile and tear properties of SMR L/ENR 25 and SMR L/SBR blends cured via a semi-efficient vulcanization system. Polym. Test. 2002, 21, 801-806. [CrossRef]

20. Manroshan, S.; Baharin, A. Effect of nanosized calcium carbonate on the mechanical proeprties of latex films. J. Appl. Polym. Sci. 2005, 96, 1550-1556. [CrossRef]

21. Deng, C.; Chen, M.; Ao, N.; Yan, D.; Zheng, Z. $\mathrm{CaCO}_{3} /$ natural rubber latex nanometer composites and its properties. J. Appl. Polym. Sci. 2006, 101, 3442-3447. [CrossRef]

22. Ghari, H.S.; Jalali-Arani, A. Nanocomposites based on natural rubber, organoclay and nano-calcium carbonate: Study on the structure, cure behavior, static and dynamic-mechanical properties. Appl. Clay Sci. 2016, 119, 348-357. [CrossRef]

23. Fang, Q.; Song, B.; Tee, T.; Sin, L.T.; Hui, D.; Bee, S. Investigation of dynamic characteristics of nano-sized calcium carbonate added in natural rubber vulcanizate. Compos. Part B 2014, 60, 561-567. [CrossRef]

24. Moonchai, S.; Moonchai, D. Modeling and optimization of rebound resilience and hardness of defatted rice bran/calcium carbonate-filled NR vulcanisates. Polym. Test. 2013, 32, 1472-1478. [CrossRef]

25. Alam, P.; Fagerlund, P.; Hagerstrand, P.; Toyryla, J.; Amini, S.; Tadayon, M.; Miserez, A.; Kumar, V.; Pahlevan, M.; Toivakka, M. L-Lysine template $\mathrm{CaCO}_{3}$ precipitated to flax develops flowery crystal structures that improve the mechanical properties of natural fiber reinforced composites. Compos. Part A 2015, 75, 84-88. [CrossRef] 
26. Ismail, H.; Mathialagan, M. Comparative study on the effect of partial replacement of silica or calcium carbonate by bentonite on the properties of EPDM composites. Polym. Test. 2012, 31, 199-208. [CrossRef]

27. Wang, Q.; Song, Q.; Qiao, J.; Zhang, X.; Zhang, L.; Song, Z. Good dispersion of hydrophilic nanoscale calcium carbonate particles in nitrile butadiene rubber matrix. Polymer 2011, 52, 3496-3502. [CrossRef]

28. Konar, S.K.; Gu, R.; Sain, M. Preparation and characterization of baked nitrile latex foam reinforced with biomass. Ind. Crop. Prod. 2013, 42, 261-267. [CrossRef]

29. Jin, F.; Park, S. Thermo-mechanical behaviors of butadiene rubber reinforced with nano-sized calcium carbonate. Mater. Sci. Eng. A 2008, 478, 406-408. [CrossRef]

30. Badley, R.A.; Atkinson, D.; Hauser, H.; Oldani, D.; Green, J.P.; Stubbs, J.M. The structure, physical and chemical properties of the soy bean protein glycinin. Biochim. Biophys. Acta. 1975, 412, 214-228. [CrossRef]

31. Jong, L. Influence of protein hydrolysis on the mechanical properties of natural rubber composites reinforced with soy protein particles. Ind. Crop. Prod. 2015, 65, 102-109. [CrossRef]

32. Schild, N.; Wolf, B.A. Polymer-Solvent Interaction Parameters. In Polymer Handbook, 4th ed.; Brandrup, J., Immergut, E.H., Grulke, E.A., Eds.; John Wiley \& Sons: New York, NY, USA, 1999; pp. 250-262.

33. Flory, P.J. Principles of Polymer Chemistry; Cornell University Press: New York, NY, USA, 1953.

34. Van der Hoff, B.M.E.; Buckler, E.J. Transient changes in topology and energy on extension of polybutadiene networks. J. Macromol. Sci. Chem. 1967, 1,747-788. [CrossRef]

35. Trabelsi, P.A.; Albouy, P.-A.; Rault, J. Stress-induced crystallization around a cracked tip in natural rubber. Macromolecules 2002, 35, 10054-10061. [CrossRef]

36. Trabelsi, P.A.; Albouy, P.-A.; Rault, J. Effective local deformation in stretched filled rubber. Macromolecules 2003, 36, 9093-9099. [CrossRef]

37. Jong, L. Improved mechanical properties of silica reinforced rubber with natural polymer. Polym. Test. 2019, 79, 106009. [CrossRef]

38. Vilgis, T.A.; Heinrich, G.; Kluppel, M. Reinforcement of Polymer Nano-Composites: Theory, Experiments and Applications; Cambridge University Press: Cambridge, UK, 2009; pp. 174-182.

39. Chasset, R.; Thirion, P. Physics of Non-Crystalline Solids. In Proceedings of the International Conference, Delft, Netherlands, July 1964; Prins, J.A., Ed.; North-Holland Publishing Co.: Amsterdam, The Netherlands, 1965; pp. 345-359.

40. Curro, J.; Pincus, P.A. Theoretical Basis for Viscoelastic Relaxation of Elastomers in the Long-Time Limit. Macromolecules 1983, 16, 559-562. [CrossRef] 